VOL. 5 NO. 2 Halaman 101-108

$P$ - ISSN : 2580-6173

$E-I S S N: 2548-6144$

Available Online http://ojs.itekes-bali.ac.id/index.php/jrkn/index

\title{
GAMBARAN PENGETAHUAN DAN SIKAP ORANG TUA TENTANG KEKERASAN PADA ANAK DI KELURAHAN RENON, DENPASAR SELATAN
}

\section{(Parents' Knowledge and Attitude toward Violence Against Children in Renon Village South of Denpasar)}

\author{
Kadek Vira Praftini", Made Rismawan ${ }^{* *}$, Nadya Treesna Wulansari ${ }^{* * * *}$ \\ $\left.{ }^{*}\right),{ }^{* * *}$ Fakultas Kesehatan, Program Studi Ilmu Keperawatan, \\ Institut Teknologi dan Kesehatan Bali, Kota Denpasar Propinsi Bali \\ ${ }^{* *}$ Fakultas Kesehatan, Program Studi DIII Keperawatan, Institut Teknologi \\ dan Kesehatan Bali, Kota Denpasar Propinsi Bali \\ Email korespondensi: maderismawan@gmail.com
}

\begin{abstract}
ABSTRAK
Latar Belakang: Anak yang mengalami kekerasan saat ini terbilang cukup tinggi. Kekerasan pada anak menjadi fenomena gunung es karena banyak kasus yang terjadi di masyarakat tetapi tidak dilaporkan. Pengetahuan dan sikap orang tua menjadi faktor utama dalam pencegahan kekerasan pada anak.

Tujuan Penelitian: Mengidentifikasi pengetahuan dan sikap orang tua tentang kekerasan pada anak di Kelurahan Renon, Denpasar Selatan.

Metode: Penelitian deskriptif dengan pendekatan cross sectional ini dilaksanakan pada bulan Februari sampai April 2021. Sampel pada penelitian ini berjumlah 350 responden yaitu orang tua dengan anak berusia $\leq 19$ tahun yang dipilih menggunakan teknik stratified random sampling. Alat pengumpulan data yang digunakan berupa kuesioner pengetahuan dan sikap orang tua. Analisa data menggunakan analisa data dekriptif dalam frekuensi dan persentase.

Hasil: Hasil penelitian menunjukkan bahwa pengetahuan dan sikap responden tertinggi adalah baik yaitu sebanyak 343 responden (98\%) dan 228 responden (65,1\%).

Kesimpulan: Pengetahuan dan sikap responden tentang kekerasan pada anak sudah baik. Hal ini dapat menjadi modal awal untuk mencegah kejadian kekerasan pada anak khususnya di Kelurahan Renon.
\end{abstract}

Kata kunci: Pengetahuan Orang Tua, Sikap Orang Tua, Kekerasan Pada Anak.

\section{ABSTRACT}

Background: Children who experience violence today are quite high. Violence against children is an iceberg phenomenon because many cases occur in the community but are not reported. Knowledge and attitudes of parents are the main factors in preventing violence against children.

Purpose: To identify knowledge and attitudes of parents toward violence against children in Renon Village, South of Denpasar.

Methods: This descriptive study with a cross sectional approach was carried out from February to April 2021. The sample in this study amounted to 350 respondents, namely parents with children aged $\leq 19$ years who were selected using stratified random sampling technique. Data collection tools used in the form of a questionnaire of knowledge and attitudes of parents. Data analysis used descriptive data analysis in frequency and percent- 
and percentage.

Results: The results showed that the knowledge and attitudes of the highest respondents were good, as many as 343 respondents (98\%) and 228 respondents (65.1\%).

Conclusion: Respondents' knowledge and attitudes about violence against children are good. This can be an initial resource to prevent violence against children, especially in Renon Village.

Keywords: Child Violence, Parental Attitude, Parental Knowledge.

\section{LATAR BELAKANG}

Anak didefinisikan sebagai individu yang berada dalam satu rentang perubahan perkembangan yang dimulai dari bayi hingga remaja. Definisi kekerasan terhadap anak menurut WHO mencakup semua bentuk perlakuan yang salah baik secara fisik dan/atau emosional, seksual, penelantaran, dan eksploitasi yang berdampak atau berpotensi membahayakan kesehatan anak, perkembangan anak, atau harga diri anak dalam konteks hubungan tanggung jawab (WHO, 2017)

Komisi Perlindungan Anak Indonesia (KPAI) mencatat selama periode 2015-2016 jumlah kasus pengaduan anak meningkat dari 4.309 kasus menjadi 4.622 kasus. Selanjutnya tahun 2017 berjumlah 4.579 kasus dan tahun 2018 terdapat 4.485 kasus (KPAI, 2016). Sementara itu, Badan Pemberdayaan Perempuan dan Anak (BP2A) Provinsi Bali menyebutkan 196 anak mengalami kasus kekerasan di Bali pada tahun 2015. Lebih lanjut, Kepala Dinas Pemberdayaan Perempuan dan Perlindungan Anak (P3A) Provinsi Bali menyatakan ada peningkatan kasus kekerasan pada anak antara tahun 2017 -2018. Terjadi peningkatan 15,2\% kasus dari 223 kasus di tahun 2017 menjadi 257 kasus di tahun 2018, dengan kasus terbanyak terjadi di Kota Denpasar (Kadis P3A Bali, 2019).

Faktor penyebab terjadinya kekerasan pada anak secara umum disebabkan karena stres dalam keluarga. Stres dalam keluarga tersebut bisa berasal dari anak, orang tua atau dalam situasi tertentu (Muhith, 2015). KPAI menyatakankan bahwa $70 \%$ orang tua belum mampu mengasuh anak, mereka menggunakan metode yang tidak cocok dengan zaman sekarang (KPAI, 2016). Orang tua menerapkan cara asuh yang hanya menyalin dari apa yang mereka dapat ketika kecil, tanpa mempelajari perubahan zaman.

Hasil penelitian yang dilakukan oleh Noni, Tri, dan Witri (2014) menyebutkan bahwa sebagian besar warga Kecamatan Paniai Timur, Papua mempunyai pengetahuan, sikap, dan perilaku baik terhadap pencegahan kekerasan pada anak. Selain itu, pengetahuan dan sikap berhubungan dengan perilaku orang tua. Sejalan dengan penelitian diatas, hasil penelitian yang dilakukan oleh Dedi, Neti, dan Ariska (2018) menunjukkan bahwa hasil pengetahuan ibu berada pada kategori tinggi $(59,6 \%)$ dan sikap berada pada kategori baik $(56,7 \%)$. Selain itu, terdapat hubungan antara pengetahuan tentang perilaku kekerasan dengan sikap ibu kepada anak di Kecamatan Meuraxa, Kota Madani Banda Aceh.

Kesimpulan yang dapat ditarik adalah sikap dan pengetahuan orang tua tentang kekerasan pada anak sangat penting karena akan sangat berpengaruh terhadap perkembangannya baik psikis maupun fisik anak. Anak yang mengalami kekerasan pada saat ini terbilang cukup tinggi. Kekerasan pada anak menjadi fenomena gunung es yang mana banyak kasus yang terjadi di masyarakat tetapi tidak dilaporkan. Sikap dan pengetahuan orang tua menjadi faktor utama dalam pencegahan kekerasan pada anak. Selain itu, peneliti belum menemukan penelitian sejenis yang dilaksanakan di wilayah Kelurahan Renon, Denpasar Selatan. Berdasarkan uraian diatas, peneliti tertarik untuk mengetahui gambaran pengetahuan dan sikap orang tua tentang kekerasan pada anak khususnya di Kelurahan Renon, Denpasar Selatan.

\section{METODE}

Penelitian deskriptif dengan pendekatan cross sectional ini dilakukan di Kelurahan Renon, Denpasar Selatan dan dilakukan pada Februari sampai April 2021. Populasi dalam penelitian ini adalah orang tua yang memiliki anak usia $\leq 19$ tahun yang berjumlah 2.802 orang (Kelurahan Renon, 2020). Tiga ratus lima puluh orang tua terpilih menjadi responden menggunakan teknik stratified random sampling. Kuesioner pada penelitian ini dikembangkan oleh peneliti yang terdiri dari tiga bagian dengan total 24 pertanyaan. Bagian pertama tentang karakteristik responden terdiri dari 4 pertanyaan. Sementara itu, bagian kedua terdiri dari 10 pertanyaan tentang 
pengetahuan orang tua tentang kekerasan pada anak. Bagian ketiga terdiri dari 10 pertanyaan tentang sikap orang tua tentang kekerasan pada anak. Validitas kuesioner menggunakan teknik face validity. Data yang terkumpul kemudian dianalisis menggunakan teknik analisa deskriptif dalam frekuensi dan persentase. Penelitian ini mendapat ijin dari Komisi Etik Penelitian ITEKES Bali (No. 03.0116/KEPITEKES-BALI/III/2021).

\section{HASIL}

\section{Karakteristik Responden}

Sampel penelitian berdasarkan karakteristiknya yaitu berdasarkan umur, jenis kelamin, pendidikan terakhir dan status pekerjaan dapat didistribusikan ke dalam tabel distribusi sebagai berikut.

Tabel 1. Karakteristik Responden $(n=350)$

\begin{tabular}{lll}
\hline $\begin{array}{l}\text { Karakteristik } \\
\text { Responden }\end{array}$ & $\begin{array}{l}\text { Frekuen- } \\
\text { si } \\
\text { (f) }\end{array}$ & $\begin{array}{l}\text { Persen- } \\
\text { tase } \\
\text { (\%) }\end{array}$ \\
\hline Umur (tahun) & & \\
$18-25$ & 8 & 2,3 \\
$26-30$ & 37 & 10,6 \\
$>30$ & 305 & 87,1 \\
& & \\
Jenis Kelamin & & \\
Laki-laki & 164 & 46,9 \\
Perempuan & 186 & 53,1 \\
& & \\
Pendidikan & & \\
Tidak tamat & 7 & 2,0 \\
SD & 10 & 2,9 \\
SMP & 41 & 11,7 \\
SMA & 153 & 43,7 \\
PT & 139 & 39,7 \\
& & \\
Pekerjaan & & \\
Tidak Bekerja & 95 & 27,1 \\
Bekerja & 255 & 72,9 \\
& & \\
\hline
\end{tabular}

Hasil penelitian menunjukkan bahwa karakteristik dari 350 responden orang tua dikelompokkan berdasarkan umur yaitu sebagian besar responden memiliki umur $>30$ tahun sebanyak 305 responden $(87,1 \%)$, umur 26-30 tahun sebanyak 37 responden $(10,6 \%)$, dan 18-25 tahun sebanyak 8 responden $(2,3 \%)$. Berdasarkan jenis kelamin dari 350 responden sebagian besar responden berjenis kelamin perempuan yaitu sebanyak 186 responden $\quad(53,1 \%)$ sedangkan laki-laki sebanyak 164 responden (46,9\%).

Berdasarkan pendidikan terakhir dari 350 responden sebagian besar responden berpendidikan SMA sebanyak 153 responden $(43,7 \%)$, perguruan tinggi sebanyak 139 responden $(39,7 \%)$, SMP sebanyak 41 responden $(11,7 \%)$, SD sebanyak 10 responden $(2,9 \%)$ dan tidak tamat sebanyak 7 responden $(2,0 \%)$. Sedangkan berdasarkan pekerjaan dapat diketahui dari 350 responden sebagian besar responden bekerja yaitu sebanyak 255 responden $(72,9 \%)$ sedangkan yang tidak bekerja sebanyak 95 responden $(27,1 \%)$.

\section{Variabel Penelitian Sikap Orang Tua}

Tabel 2. Gambaran Sikap Orang Tua tentang Kekerasan Pada Anak di Kelurahan Renon Denpasar Selatan $(n=350)$

\begin{tabular}{lll}
\hline $\begin{array}{l}\text { Kategori } \\
\text { Sikap }\end{array}$ & $\begin{array}{l}\text { Frekuensi } \\
\text { (f) }\end{array}$ & Persen (\%) \\
& & \\
Baik & 228 & 65,1 \\
Cukup & 112 & 34,9 \\
\hline
\end{tabular}

Berdasarkan Tabel 2 dapat diketahui dari 350 responden, berdasarkan sikap orang tua dalam kategori baik sebanyak 228 responden $(65,1 \%)$, cukup sebanyak 112 responden $(34,9 \%)$ dan tidak ada yang termasuk kategori kurang. Sebagian besar sikap orang tua di Kelurahan Renon Denpasar Selatan adalah baik sebanyak 228 responden $(65,1 \%)$.

\section{Pengetahuan Orang Tua}

Tabel 3. Gambaran Pengetahuan Orang Tua tentang Kekerasan Pada Anak di Kelurahan Renon Denpasar Selatan $(\mathrm{n}=350)$

\begin{tabular}{lll}
\hline $\begin{array}{l}\text { Kategori } \\
\text { Pengeta } \\
\text { huan }\end{array}$ & Frekuensi (f) & $\begin{array}{l}\text { Persen } \\
\mathbf{( \% )}\end{array}$ \\
Baik & 343 & \\
Cukup & 6 & 98,0 \\
Kurang & 1 & 1,7 \\
\hline
\end{tabular}

Berdasarkan Tabel 3 dapat diketahui dari 350 responden, bahwa berdasarkan pengetahuan orang tua dalam kategori baik sebanyak 343 responden (98\%), cukup sebanyak 6 responden $(1,7 \%)$ dan kurang sebanyak 1 responden $(0,3 \%)$. Sebagian besar pengetahuan orang tua di Kelurahan Renon Denpasar Selatan adalah baik sebanyak 343 responden (98\%).

Jurnal Riset Kesehatan Nasional hal. 103 


\section{PEMBAHASAN \\ Karakteristik Orang Tua}

Hasil penelitian karakteristik orang tua tentang kekerasan pada anak di Kelurahan Renon Denpasar Selatan menunjukkan bahwa umur orang tua yang terbanyak adalah $>30$ tahun. Secara umum orang tua yang memiliki umur $>30$ tahun cenderung memiliki sikap dan pengetahuan yang lebih baik dibandingkan dengan orang tua yang memiliki umur kurang dari 30 tahun. Hal ini dikarenakan kematangan umur cenderung lebih mempengaruhi sikap dan pengetahuan orang tua untuk dapat mengambil keputusan. Hal ini sesuai dengan hasil teori yang dikemukakan oleh Wawan (2011) yang menyatakan bahwa, semakin bertambah usia seseorang akan semakin berkembang pula daya tangkap dan pola pikirnya, sehingga pengetahuan yang diperoleh akan semakin baik. Menurut hasil penelitian berdasarkan jenis kelamin dari 350 responden sebagian besar responden berjenis kelamin perempuan yaitu sebanyak 186 responden.

Berdasarkan pendidikan terakhir, dari 350 responden sebagian besar responden berpendidikan SMA sebanyak 153 responden. Pada penelitian ini responden orang tua secara umum didominasi oleh pendidikan SMA. Hasil penelitian ini sesuai dengan teori menurut Riyanto dan Budiman (2013) yang menyatakan bahwa pendidikan mempengaruhi proses belajar, makin tinggi pendidikan seseorang, makin mudah orang tersebut untuk menerima informasi. Pengetahuan sangat erat kaitannya dengan pendidikan dimana diharapkan seseorang dengan pendidikan tinggi, orang tersebut semakin luas pula pengetahuannya.

Sedangkan berdasarkan pekerjaan dapat diketahui dari 350 responden sebagian besar responden bekerja yaitu sebanyak 255 responden. Hasil teori yang dikemukakan oleh Riyanto dan Budiman (2013) menyatakan bahwa status ekonomi seseorang juga akan menentukan tersedianya fasilitas yang diperlukan untuk kegiatan tertentu sehingga status sosial ekonomi akan mempengaruhi pengetahuan seseorang. Dalam sebuah model yang disebut "The Abusive Environment Model", Ismail (1995 dikutip di Suyanto, 2010) menjelaskan bahwa faktor penyebab terjadinya kekerasan terhadap anak-anak salah satunya yaitu karena faktor lingkungan sosial seperti kondisi kemiskinan dalam masyarakat dan tekanan nilai materialistik, kondisi sosial ekonomi yang rendah, status wanita yang rendah, sistem keluarga patriarki, nilai masyarakat yang terlalu individualisme.

Eva dan Nina (2014) menyatakan bahwa beberapa faktor utama yang menjadi penyebab terjadinya tindak kekerasan orang tua terhadap anak yaitu faktor rendahnya ekonomi, faktor rendahnya pendidikan orang tua, faktor lingkungan sosial dan faktor psikologis.

\section{Gambaran Sikap Orang Tua}

Sebagian responden memiliki kategori sikap baik karena delapan pernyataan dijawab dengan benar oleh sebagian besar responden. Kedelapan pernyataan yang dijawab dengan benar oleh sebagian besar responden yaitu pernyataan tentang "Kekerasan pada anak adalah hal yang sangat merugikan", "Kekerasan pada anak dapat dicegah dengan memberikan perhatian dan kasih sayang pada anak", "Kekerasan pada anak sering terjadi di masyarakat tetapi tidak dilaporkan", "Kekerasan pada anak berdampak pada kesehatan mental anak seperti cemas berlebih, gangguan makan dan gangguan tidur", "Pemberian pola asuh yang tepat dapat mencegah kekerasan pada anak", "Orang tua berhak marah jika anak melakukan kesalahan yang tidak disengaja", "Hubungan orang tua yang harmonis dapat menyebabkan kekerasan pada anak", dan "Orang tua harus mengetahui tanda-tanda kekerasan anak, sehingga dapat mengenali anak yang menjadi korban kekerasan". Sikap sebagian besar responden pada penelitian ini baik karena mayoritas orang tua menganggap bahwa kekerasan pada anak dapat dicegah dengan memberikan perhatian dan kasih sayang pada anak. Orang tua merupakan sosok paling penting dalam membentuk karakter anak selain guru di sekolah. Dalam satu hari, sebagian besar waktu anak dihabiskan bersama orang tua (Muhadi, 2016).

Orang tua sebagai orang pertama yang bertanggungjawab terhadap masa depan anak. Adapun tanggung jawab orang tua yang perlu dibina dan disadarkan salah satunya adalah memelihara dan membesarkan anak agar anak dapat hidup secara berkelanjutan, melindungi dan menjamin kesehatan baik jasmani maupun rohani dari berbagai macam penyakit dan bahaya lingkungan dan membahagiakan anak, menanamkan nilai-nilai luhur serta menetapkan etika dan sopan santun sehingga anak dapat bergaul di masyarakat dan

Jurnal Riset Kesehatan Nasional hal. 104 
diterima dengan baik (Jannah dan Putra 2015).

Sikap sebagian kecil responden orang tua menganggap bahwa, orang tua berhak marah jika anak melakukan kesalahan yang tidak disengaja. Menurut Gelles (2004 dikutip di Huraerah, 2014) dalam Encyclopedia Article from Encarta, kekerasan terhadap anak (child abuse) dapat didefinisikan sebagai peristiwa perlukaan fisik, mental, atau seksual yang umumnya dilakukan oleh orang-orang yang mempunyai tanggung jawab terhadap kesejahteraan anak yang mana itu semua diindikasikan dengan kerugian dan ancaman terhadap kesehatan dan kesejahteraan anak.

Kekerasan psikis, meliputi penyampaian kata-kata kasar dan kotor. Anak yang mendapat perlakuan ini pada umumnya menunjukan gejala perilaku maladaktif seperti menarik diri, pemalu, menangis jika didekati, takut keluar rumah dan takut bertemu dengan orang lain (Suharto, 1997 dikutip di Hurearah, 2012). Menurut Basoeki (1999 dikutip di Suyanto, 2010) salah satu faktor penyebab mengapa banyak terjadi penganiayaan anak dan penelantaran anak di antaranya adalah isolasi sosial, tidak adanya dukungan yang cukup dari lingkungan sekitar, tekanan sosial akibat krisis ekonomi, tidak bekerja atau tidak memiliki penghasilan dan masalah perumahan akan meningkatkan kerentanan keluarga yang akhirnya akan terjadi penganiayaan dan penelantaran anak.

Pada penelitian ini, sebagian besar responden menganggap bahwa hubungan orang tua yang tidak harmonis dapat menyebabkan kekerasan pada anak. Seorang pemerhati masalah anak dari Malaysia yakni Fatimah (1992 dikutip di Suyanto, 2010) mengungkapkan setidaknya terdapat beberapa kondisi yang menjadi faktor penyebab terjadinya kekerasan atau pelanggaran dalam keluarga yang dilakukan terhadap anak. Masalah keluarga merupakan hal yang mengacu pada situasi keluarga khususnya hubungan orang tua yang kurang harmonis.

Adapun faktor lain yaitu faktor perceraian, perceraian dapat menimbulkan problematika rumah tangga seperti hak pemeliharaan anak, pemberian kasih sayang, pemberian nafkah dan sebagainya. Dalam sebuah model yang disebut "The Abusive Environment Model", Ismail (1995 dikutip di Suyanto, 2010) menjelaskan bahwa faktor penyebab terjadinya kekerasan terhadap anak-anak sesungguhnya dapat ditinjau dari tiga aspek, yaitu hubungan yang tidak harmonis sehingga mempengaruhi watak, adanya proses kehamilan atau kelahiran yang sulit dan kehadiran anak yang tidak dikehendaki.

Sikap sebagian kecil responden orang tua menganggap bahwa anak-anak yang selalu diberikan perhatian dan kasih sayang dapat mengalami perkembangan ego yang tidak stabil. Selama ini, berbagai kasus telah membuktikan bawa terjadinya child abuse (penganiayaan anak), baik child abuse maupun child neglect dapat memberikan dampak pada kesehatan fisik dan mental anak. Menurut Saptadari (2002 dikutip di Suyanto, 2010) menjelaskan bahwa, dampak yang dialami anak-anak yang menjadi korban tindak kekerasan adalah kurangnya motivasi atau harga diri, problem kesehatan mental misalnya kecemasan berlebihan, problem dalam hal makan dan susah tidur, sakit yang serius dan luka, dan mengembangkan perilaku agresif atau menjadi pemarah bahkan menjadi pendiam atau suka menarik diri dari pergaulan.

Menurut Levitan dkk (dalam Suyanto, 2010) dari hasil studinya memberikan sugesti adanya hubungan antara pengalaman yang traumatis pada anak usia dini dan timbulnya kelompok gejala depresi dan maniak pada masa dewasa. Reaksi jangka panjang dari anak-anak yang mengalami abuse dan neglect berdasarkan hasil analisis retrospective menunjukkan bahwa apabila terjadi sejak masa awal dari kehidupan anak bisa menyebabkan kecenderungan terjadinya depresi yang serius pada kehidupan dikemudian harinya. Anak-anak yang dengan sengaja kurang diberi kasih sayang bisa mengalami perkembangan struktur ego yang tidak stabil dan rentan untuk terjadinya psikosis pada kemudian hari.

Wawan dan Dewi (2011), menyatakan bahwa faktor-faktor yang mempengaruhi pembentukan sikap yaitu pengalaman pribadi, pengaruh orang lain yang dianggap penting, pengaruh kebudayaan, media massa, lembaga pendidikan dan lembaga agama, serta faktor emosional. Sikap orang tua yang salah akan membentuk persepsi dan pola piker yang salah dalam mendidik anak. Sikap karena ketidaktauan tersebut yang akan menyebabkan orang tua berprilaku salah terhadap anak (Wawan dan Dewi, 2011).

Hasil penelitian yang dilakukan oleh Isnaini dan Siti (2017) menunjukkan bahwa menunjukkan bahwa, sikap ibu terhadap 
kekerasan pada anak lebih banyak bersikap negatif yaitu sebanyak 33 (56\%) dibandingkan ibu yang bersikap positif sebanyak 26 (44\%). Dari hasil tersebut dapat ditarik kesimpulan bahwa responden lebih dominan memiliki sikap negatif yaitu sikap yang tidak mendukung terhadap kekerasan pada anak sehingga tidak berisiko melakukan kekerasan pada anak. Berbeda dari hasil penelitian tersebut, hasil penelitian yang dilakukan oleh Icharma, Budhy, dan Yustiana (2017) menunjukkan bahwa, sikap orang tua tentang pencegahan kekerasan seksual pada anak usia prasekolah di Dusun Pringwulung Condongcatur sebagian besar positif (mendukung).

Sebagian besar sikap orang tua di Kelurahan Renon Denpasar Selatan adalah baik sebanyak 228 responden $(65,1 \%)$. Hal ini menggambarkan bahwa sebagian besar sikap orang tua tentang kekerasan pada anak di Kelurahan Renon Denpasar Selatan adalah baik.

\section{Gambaran Pengetahuan Orang Tua}

Berdasarkan hasil penelitian maka sebagian besar responden memiliki kategori pengetahuan baik. Sebagian responden memiliki kategori pengetahuan baik karena sepuluh pernyataan dijawab dengan benar oleh sebagian besar responden. Kesepuluh pernyataan dijawab dengan benar oleh sebagian besar responden yaitu "Kekerasan pada anak merupakan perbuatan yang disengaja dan menimbulkan kerugian atau bahaya terhadap anak -anak secara fisik maupun emosional", "Kekerasan fisik adalah penyiksaan, pemukulan dan penganiayaan terhadap anak dengan atau tanpa menggunakan benda-benda tertentu, yang menimbulkan luka-luka fisik atau kematian ada anak", "Kekerasan psikis meliputi penyampaian kata-kata kasar dan kotor, memperlihatkan buku, gambar dan film pornografi pada anak", "Kekerasan seksual dapat berupa meminta atau menekan anak untuk melakukan aktivitas seksual antara anak dengan orang dewasa", "Kekerasan anak dapat terjadi karena masa lalu orang tua yang dibesarkan dengan kekerasan", "Tanda terjadinya kekerasan pada anak adalah anak tampak ceria terutama pada orang tua", "Penganiayaan pada anak dapat mengakibatkan dampak buruk pada kesehatan fisik dan mental anak", "Anak yang menjadi korban kekerasan dapat memberikan pengaruh buruk pada ingatan anak bahkan hingga anak dewasa", "Dampak kekerasan pada anak dalam masyarakat yaitu pewarisan lingkaran kekerasan secara turun temurun atau dari generasi ke generasi", dan "Anak-anak yang terlantar mengalami pertumbuhan dan perkembangan yang optimal". Pengetahuan sebagian besar responden pada penelitian ini baik karena mayoritas orang tua menganggap bahwa kekerasan seksual dapat berupa meminta atau menekan anak untuk melakukan aktivitas seksual antara anak dengan orang dewasa. Menurut Suharto (1997 dikutip di Hurearah, 2012) mengelompokkan child abuse menjadi physical abuse (kekerasan secara fisik), psychological abuse (kekerasan secara psikologis, sexual abuse (kekerasan secara seksual) dan social abuse (kekerasan secara sosial).

Pengetahuan sebagian kecil responden orang tua menganggap bahwa, dampak kekerasan pada anak dalam masyarakat yaitu pewarisan lingkaran kekerasan secara turun temurun atau dari generasi ke generasi. Menurut Basoeki (1999 dikutip di Suyanto, 2010) menyatakan bahwa faktor penyebab lain mengapa banyak terjadi penganiayaan dan penelantaran anak diantaranya adalah orang tua yang dahulu dibesarkan dengan kekerasan cenderung meneruskan pendidikan tersebut kepada kepada anak-anaknya.

Selanjutnya, mayoritas orang tua menganggap bahwa tanda terjadinya kekerasan pada anak adalah anak tampak ceria terutama pada orang tua. Menurut Fontana (1973 dikutip di Suyanto, 2010) adapun hal yang perlu dicurigai adanya penganiayaan pada anak yaitu anak tampak ketakutan terutama pada orang tua, adanya luka yang tidak dengan semestinya, anak kekurangan gizi, anak seringkali menangis serta anak kerap kali terlalu hati-hati terhadap larangan orang tua.

Pengetahuan sebagian kecil responden orang tua menganggap bahwa anak-anak yang terlantar mengalami pertumbuhan dan perkembangan yang optimal. Pada anak-anak yang mengalami penelantaran dapat terjadi kegagalan dalam tumbuh kembangnya seperti malnutrisi. Kadang ada dari mereka mengalami perbaikan hormon pertumbuhannya dan kemudian mengejar ketinggalan pertumbuhan yang pernah dialaminya (Suyanto, 2010).

Menurut Riyanto dan Budiman (2013) menyatakan bahwa faktor-faktor yang mempengaruhi pengetahuan adalah pendidikan, informasi atau media massa, sosial budaya dan ekonomi, pengalaman serta usia. 
Pengetahuan merupakan domain yang sangat penting untuk terbentuknya tindakan orang tua, karena pengetahuan orang tua yang benar tentang kekerasan pada anak dapat mempengaruhi bagaimana orang tua akan bersikap lebih benar (Notoadmodjo, 2012).

Hasil penelitian yang dilakukan oleh Suko (2017) diperoleh hasil bahwa ibu yang memiliki pengetahuan baik tentang kekerasan pada anak usia 0-5 tahun sebanyak $11 \%$. Berbeda dari hasil penelitian diatas, hasil penelitian yang dilakukan oleh Atsye, Yenny, dan Astri (2017) menunjukkan bahwa, sebagian besar responden memiliki pengetahuan cukup dengan persentase sebesar $47 \%$.

Sebagian besar pengetahuan orang tua di Kelurahan Renon Denpasar Selatan adalah baik sebanyak 343 responden $(9,80 \%)$. Hal ini menggambarkan bahwa sebagian besar pengetahuan orang tua tentang kekerasan pada anak di Kelurahan Renon Denpasar Selatan adalah baik.

\section{SIMPULAN}

Karakteristik orang tua di Kelurahan Renon Denpasar Selatan menunjukkan umur orang tua yang terbanyak adalah $>30$ tahun sebanyak 305 responden $(87,1 \%)$, sebagian besar responden berjenis kelamin perempuan yaitu sebanyak 186 responden $(53,1 \%)$, sebagian besar responden berpendidikan SMA sebanyak 153 responden $(43,7 \%)$, dan sebagian besar responden bekerja yaitu sebanyak 255 responden $(72,9 \%)$. Sikap orang tua tentang kekerasan pada anak di Kelurahan Renon Denpasar Selatan sebagian besar pada kategori baik yaitu sebanyak 228 responden $(65,1 \%)$ dan kategori cukup sebanyak 112 responden $(34,9 \%)$. Pengetahuan orang tua tentang kekerasan pada anak di Kelurahan Renon Denpasar Selatan sebagian besar pada kategori baik yaitu sebanyak 343 responden (98\%), cukup sebanyak 6 responden $(1,7 \%)$ dan kurang sebanyak 1 responden $(0,3 \%)$. Pelayanan kesehatan yang mewilayahi Kelurahan Renon perlu melakukan kegiatan edukasi dan pembinaan kepada para orang tua karena masih ditemukannya kategori cukup dan kurang pada sikap maupun pengetahuan orang tua tentang kekerasan pada anak. Para orang tua juga harus mampu secara aktif mencari informasi tentang pola asuh orang tua yang tepat agar mampu meningkatkan pengetahuan dan sikap untuk mencegah terjadinya kekerasan pada anak.

\section{KEPUSTAKAAN}

Atsye, T. M., Yenny, M., \& Astri, J. M. (2017). Tingkat pengetahuan orang tua tentang kekerasan pada anak di Kampung Beeng. (Online), (http:// ejournal.polnustar.ac.id/jis/article/ view/168., diakses tanggal 9 Oktober 2020, jam 20.00 WITA).

Budiman, \& Riyanto, A. (2013). Kapita selekta kuesioner pengetahuan dan sikap dalam penelitian kesehatan. Jakarta: Salemba Medika.

Dedi, S., Neti, H., \& Ariska M. S. (2018). Hubungan pengetahuan ibu dengan sikap kekerasan kepada anak di Kecamatan Meuraxa. (Online), (http:// jurnal.abulyatama.ac.id/index.php/ acehmedika/article/viewFile/165/165., diakses tanggal 10 November 2020, jam 18,30 WITA).

Eva, H \& Nina, S. S. (2014). Faktor-faktor apa yang menjadi penyebab terjadinya kekerasan orang tua terhadap anak. (Online), (http://www.ojs.uma.ac.id/ index.php/jppuma/article/ view/580/924., diakses tanggal 9 Oktober 2020, JAM 14.00 WITA)

Huraerah, A. (2012). Kekerasan terhadap anak. (M. A. Elwa, Ed) (Edisi III). Bandung: Nuansa Cendikia.

Isnaini, P., \& Siti, I. (2017). Gambaran sikap ibu terhadap kekerasan pada anak di wilayah kerja Puskesmas Mergangsan Yogyakarta. Diperoleh tanggal 9 Oktober 2020 ,

dari http://digilib2.unisayogya.ac.id/ handle/123456789/1815

Komisi Perlindungan Anak Indonesia (2016). Data kekerasan anak. Jakarta: Komisi Perlindungan Anak Indonesia

Kementerian Pemberdayaan Perempuan dan Pemberdayaan Anak. (Eds.). (2017). Mengakhiri kekerasan terhadap perempuan dan anak di indonesia. Jakarta: Badan Pusat Statistik

Noni, Y., Tri I. P., Witri, H. (2014). Pengetahuan, sikap dan perilaku orang tua tentang kekerasan fisik pada anak di Papua. (Online), (https:// jurnal.unimus.ac.id/index.php/ psn12012010/article/view/11., diakses tanggal 11 November 2020, jam 15.30 WITA).

Notoatmodjo, S. (2014). Pengetahuan dan perilaku kesehatan. Jakarta: Rhineka Cipta

Jurnal Riset Kesehatan Nasional hal. 107 
Sinha, M. (2013). "Measuring violence against women: Statistical trends", Juristat, Canadian Centre for Justice Statistics, no. 85-002-X

Suyanto, B. (2010). Masalah sosial anak (Edisi I). Jakarta: Kencana

Wawan, A., \& Dewi. (2011). Teori \& pengukuran pengetahuan, sikap dan perilaku. Yogyakarta: Nuha Medika
Wawan, A., \& Dewi, M. (2016). Teori \& pengukuran pengetahuan, sikap dan perilaku manusia. Yogyakarta: Nuha Medika

World Health Organization (WHO). Definisi anak. Diakses pada tanggal 5 Desember 2020, dari http:// scholar.unand.ac.id/37998/2/bab\% 201.PDF 